\title{
Stimulation of Suicidal Erythrocyte Death by Ceritinib-Treatment of Human Erythrocytes
}

\author{
Abdulla Al Mamun Bhuyan ${ }^{a}$ Elena Signoretto ${ }^{a, b}$ Rosi Bissinger ${ }^{a} \quad$ Florian Lang $^{a, c}$ \\ aDepartments of Cardiology, Cardiovascular Medicine and Physiology, Eberhard-Karls-University \\ of Tuebingen, Tuebingen, Germany; 'bepartment of Pharmacological and Biomolecular Sciences, \\ Università degli Studi di Milano, Milano Italy; 'Department of Molecular Medicine II, Heinrich Heine \\ University Duesseldorf, Duesseldorf, Germany
}

\section{Key Words}

Phosphatidylserine $\bullet$ Cell volume $•$ Eryptosis $・$ Ionomycin $•$ Calcium

\begin{abstract}
Background/Aims: The anaplastic lymphoma kinase (ALK) inhibitor ceritinib is utilized for the treatment of ALK positive non-small cell lung carcinoma. Side effects of the drug include decrease of blood hemoglobin concentration. Possible causes of anemia include stimulation of suicidal erythrocyte death or eryptosis, which is characterized by cell shrinkage and cell membrane scrambling with phosphatidylserine translocation to the erythrocyte surface. Signaling of eryptosis includes increase of cytosolic $\mathrm{Ca}^{2+}$ activity $\left(\left[\mathrm{Ca}^{2+}\right]_{i}\right)$, oxidative stress, ceramide, staurosporine sensitive protein kinase C, SB203580 sensitive p38 kinase, D4476 sensitive casein kinase 1 , and ZVAD sensitive caspases. The present study explored, whether ceritinib induces eryptosis and, if so, to shed light on the cellular mechanisms involved. Methods: Phosphatidylserine exposure at the cell surface was estimated from annexin-Vbinding, cell volume from forward scatter, $\left[\mathrm{Ca}^{2+}\right]_{i}$ from Fluo3-fluorescence, ROS formation from DCFDA dependent fluorescence, and ceramide abundance utilizing specific antibodies. Results: A 48 hours exposure of human erythrocytes to ceritinib $(1 \mu \mathrm{g} / \mathrm{ml})$ significantly increased the percentage of annexin-V-binding cells, significantly decreased forward scatter, significantly increased Fluo3-fluorescence, but did not significantly modify DCFDA fluorescence or ceramide abundance. The effect of ceritinib on annexin-V-binding was significantly blunted but not abolished by removal of extracellular $\mathrm{Ca}^{2+}$, by the kinase inhibitors staurosporine (1 $\mu \mathrm{M})$, SB203580 $(2 \mu \mathrm{M})$ and D4476 $(10 \mu \mathrm{M})$, as well as by caspase inhibitor zVAD $(10 \mu \mathrm{M})$. Conclusions: Ceritinib triggers cell shrinkage and phospholipid scrambling of the erythrocyte cell membrane, an effect at least in part due to $\mathrm{Ca}^{2+}$ entry, as well as activation of kinases and caspases.




\section{Introduction}

The anaplastic lymphoma (tyrosine) kinase (ALK) inhibitor ceritinib is utilized for the treatment of ALK positive non-small cell lung carcinoma [1-15]. The most common laboratory abnormality following ceritinib treatment is a decrease of blood hemoglobin concentration [2]. Potential causes of anemia include stimulation of suicidal erythrocyte death or eryptosis [16], which leads to rapid clearance of affected erythrocytes from circulating blood and thus to anemia [16]. Hallmarks of eryptosis include cell shrinkage [17] and cell membrane scrambling with phosphatidylserine translocation to the cell surface [16]. Eryptosis may be triggered by increase of cytosolic $\mathrm{Ca}^{2+}$ activity $\left(\left[\mathrm{Ca}^{2+}\right]_{\mathrm{i}}\right)[16]$, ceramide [18], oxidative stress [16], and energy depletion [16]. Eryptosis may or may not involve caspases [16, 19, 20]. Kinases able to stimulate eryptosis include casein kinase $1 \alpha$ [21], Janus-activated kinase JAK3 [22], protein kinase C [23], and p38 kinase [24]. Kinases protecting against eryptosis include AMP activated kinase AMPK [25], cGMP-dependent protein kinase [26], PAK2 kinase [27], and sorafenib/sunitinib sensitive kinases [28, 29]. Eryptosis is triggered by multiple xenobiotics [16, 30-71].

The present study tested, whether ceritinib triggers eryptosis. To this end, human erythrocytes from healthy volunteers were exposed to ceritinib and phosphatidylserine surface abundance, cell volume, $\left[\mathrm{Ca}^{2+}\right]_{\mathrm{i}}$, ROS formation, and ceramide abundance determined by flow cytometry.

\section{Materials and Methods}

Erythrocytes, solutions and chemicals

Fresh Li-Heparin-anticoagulated blood samples were kindly provided by the blood bank of the University of Tübingen. The study is approved by the ethics committee of the University of Tübingen (184/2003 V). The blood was centrifuged at $120 \mathrm{~g}$ for $20 \mathrm{~min}$ at $21^{\circ} \mathrm{C}$ and the platelets and leukocytes-containing supernatant was disposed. Erythrocytes were incubated in vitro at a hematocrit of $0.4 \%$ in Ringer solution containing (in $\mathrm{mM}$ ) $125 \mathrm{NaCl}, 5 \mathrm{KCl}, 1 \mathrm{MgSO}_{4}, 32 \mathrm{~N}$-2-hydroxyethylpiperazine-N-2-ethanesulfonic acid (HEPES; pH 7.4), 5 glucose, 1 $\mathrm{CaCl}_{2}$, at $37^{\circ} \mathrm{C}$ for 48 hours. Where indicated, erythrocytes were exposed for 48 hours to ceritinib (Selleckchem, Munich, Germany). In order to estimate the impact of $\mathrm{Ca}^{2+}$ entry, erythrocytes were exposed to ceritinib in the presence and absence of extracellular $\mathrm{Ca}^{2+}$. To test for an involvement of kinases, erythrocytes were exposed for 48 hours to a combination of ceritinib and protein kinase C inhibitor staurosporine (Enzo Life Sciences, Lörrach, Germany), p38 kinase inhibitor SB 203580 (Tocris bioscience, Bristol, UK) or casein kinase inhibitor D4476 (Tocris Bioscience, Bristol, UK). To test for an involvement of caspases, erythrocytes were exposed for 48 hours to a combination of ceritinib and pan-caspase inhibitor zVAD (Enzo Life Sciences, Lörrach, Germany).

\section{Annexin-V-binding and forward scatter}

After incubation under the respective experimental condition, a $150 \mu \mathrm{l}$ cell suspension of erythrocytes was centrifuged at $1600 \mathrm{rpm}$ for $3 \mathrm{~min}$ and, after discarding the supernatant, the erythrocytes were stained with Annexin-V-FITC (1:200 dilution; ImmunoTools, Friesoythe, Germany) in this solution at $37^{\circ} \mathrm{C}$ for 15 min under protection from light. The annexin-V-abundance at the erythrocyte surface was subsequently determined on a FACS Calibur (BD, Heidelberg, Germany). Annexin-V-binding was measured with an excitation wavelength of $488 \mathrm{~nm}$ and an emission wavelength of $530 \mathrm{~nm}$. A marker (M1) was placed to set an arbitrary threshold between annexin-V-binding cells and control cells. The same threshold was used for untreated and ceritinib treated erythrocytes. A dot plot of forward scatter (FSC) vs. side scatter (SSC) was set to linear scale for both parameters. The threshold of forward scatter was set at the default value of " 52 ".

Intracellular $\mathrm{Ca}^{2+}$

After incubation, erythrocytes were washed in Ringer solution and then loaded with Fluo-3/AM (Biotium, Hayward, USA) in Ringer solution containing $5 \mathrm{mM} \mathrm{CaCl}_{2}$ and $5 \mu \mathrm{M}$ Fluo-3/AM. The cells were incubated at $37^{\circ} \mathrm{C}$ for $30 \mathrm{~min}$ and washed once in Ringer solution containing $5 \mathrm{mM} \mathrm{CaCl} \mathrm{Cl}_{2}$ The Fluo-3/ AM-loaded erythrocytes were resuspended in $200 \mu$ Ringer solution. Then, $\mathrm{Ca}^{2+}$-dependent fluorescence 


\section{Cellular Physiology Cell Physiol Biochem 2016;40:1129-1140 \begin{tabular}{l|l|l} 
and Biochemistry & Dublished online: December 14, 2016 & $\begin{array}{l}\text { (c) } 2016 \text { The Author(s). Published by S. Karger AG, Basel } \\
\text { www.karger.com/cpb }\end{array}$
\end{tabular} \\ Bhuyan et al.: Ceritinib-Induced Eryptosis}

intensity was measured in FL-1 with an excitation wavelength of $488 \mathrm{~nm}$ and an emission wavelength of $530 \mathrm{~nm}$ on a FACS Calibur. Afterwards, the geomean of the $\mathrm{Ca}^{2+}$ dependent fluorescence was determined.

Reactive oxygen species (ROS)

Oxidative stress was determined utilizing 2',7'-dichlorodihydrofluorescein diacetate (DCFDA). After incubation, a $150 \mu \mathrm{l}$ suspension of erythrocytes was washed in Ringer solution and then stained with DCFDA (Sigma Aldrich, Hamburg, Germany) in Ringer solution containing DCFDA at a final concentration of $10 \mu$ M. Erythrocytes were incubated at $37^{\circ} \mathrm{C}$ for $30 \mathrm{~min}$ in the dark and then washed two times in Ringer solution. The DCFDA-loaded erythrocytes were resuspended in $200 \mu$ l Ringer solution, and ROS-dependent fluorescence intensity was measured in FL-1 at an excitation wavelength of $488 \mathrm{~nm}$ and an emission wavelength of 530 $\mathrm{nm}$ on a FACS Calibur (BD). Subsequently, the geomean of the ROS-dependent fluorescence was determined.

\section{Ceramide abundance}

To determine the ceramide abundance at the erythrocyte surface, a monoclonal antibody was used. After incubation, cells were stained for $1 \mathrm{~h}$ at $37^{\circ} \mathrm{C}$ with $1 \mu \mathrm{g} / \mathrm{ml}$ anti-ceramide antibody (clone MID 15B4; Alexis, Grünberg, Germany) in phosphate-buffered saline (PBS) containing $0.1 \%$ bovine serum albumin (BSA) at a dilution of 1:10. After two washing steps with PBS-BSA, cells were stained for 30 min with polyclonal fluorescein-isothiocyanate (FITC)-conjugated goat anti-mouse IgG and IgM specific antibody (BD Pharmingen, Hamburg, Germany) diluted 1:50 in PBS-BSA. Unbound secondary antibody was removed by repeated washing with PBS-BSA. Samples were then analyzed by flow cytometric analysis in FL-1 at an excitation wavelength of $488 \mathrm{~nm}$ and an emission wavelength of $530 \mathrm{~nm}$. Finally, the geomean of the ceramide dependent fluorescence was determined.

Hemolysis

Following incubation, the erythrocyte suspension was centrifuged for $3 \mathrm{~min}$ at $1600 \mathrm{rpm}, 4^{\circ} \mathrm{C}$, and the supernatant harvested. As a measure of hemolysis, the hemoglobin ( $\mathrm{Hb}$ ) concentration in the supernatant was determined photometrically at $405 \mathrm{~nm}$. The absorption of the supernatant of erythrocytes lysed in distilled water was defined as $100 \%$ hemolysis.

Statistics

Data are expressed as arithmetic means \pm SEM. As indicated in the figure legends, statistical analysis was made using ANOVA with Tukey's test as post-test and $t$ test as appropriate. $\mathrm{n}$ denotes the number of different erythrocyte specimens studied. Since different erythrocyte specimens used in distinct experiments are differently susceptible to triggers of eryptosis, the same erythrocyte specimens have been used for control and experimental conditions.

\section{Results}

As ceritinib treatment has been shown to trigger anemia, the present study explored the possibility that ceritinib stimulates eryptosis, the suicidal erythrocyte death characterized by cell shrinkage and phospholipid scrambling of the cell membrane with phosphatidylserine translocation to the cell surface.

Phosphatidylserine exposing erythrocytes were identified utilizing annexin-V-binding, as determined by flow cytometry. Prior to flow cytometry, the erythrocytes were incubated for 48 hours in Ringer solution without or with ceritinib $(0.5-1 \mu \mathrm{g} / \mathrm{ml})$. As shown in Fig. 1, a 48 hours exposure to ceritinib increased the percentage of phosphatidylserine exposing erythrocytes, an effect reaching statistical significance at $0.75 \mu \mathrm{g} / \mathrm{ml}$ ceritinib.

Erythrocyte volume was estimated from forward scatter which was determined utilizing flow cytometry. Again, erythrocytes were incubated for 48 hours in Ringer solution without or with ceritinib $(0.5-1 \mu \mathrm{g} / \mathrm{ml})$ prior to measurements. As illustrated in Fig. 2, ceritinib decreased erythrocyte forward scatter, an effect statistically significant at $1 \mu \mathrm{g} / \mathrm{ml}$ ceritinib concentration. 
Fig. 1. Effect of ceritinib on phosphatidylserine exposure. A. Original histogram of annexin-V-binding of erythrocytes following exposure for 48 hours to Ringer solution without (grey area) and with (black line) presence of $1 \mu \mathrm{g} / \mathrm{ml}$ ceritinib. B. Arithmetic means \pm SEM $(n=17)$ of erythrocyte annexin-V-binding following

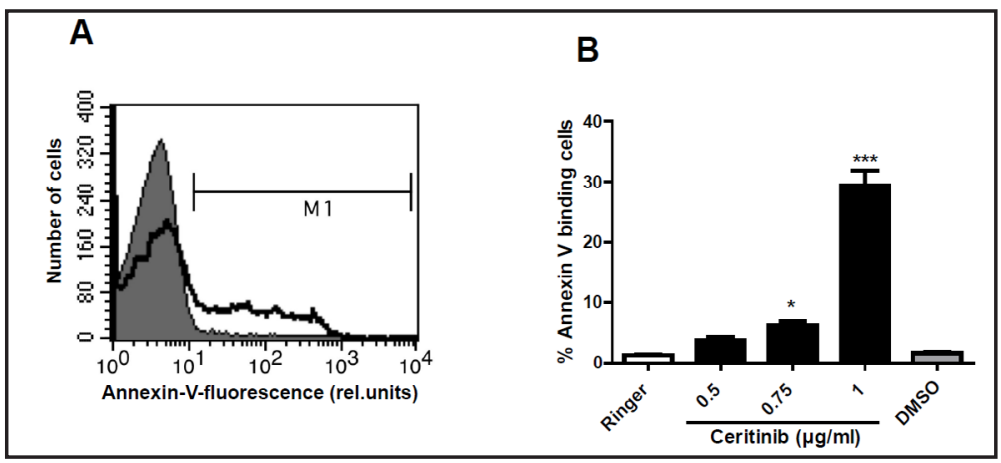
incubation for 48 hours to Ringer solution without (white bar) or with (black bars) ceritinib (0.5 - $1 \mu \mathrm{g} /$ $\mathrm{ml})$. For comparison, the effect of the solvent DMSO is shown (grey bar). ${ }^{*}(\mathrm{p}<0.05),{ }^{* * *}(\mathrm{p}<0.001)$ indicate significant difference from the absence of ceritinib (ANOVA).

Fig. 2. Effect of ceritinib on erythrocyte forward scatter. A. Original histogram of forward scatter of erythrocytes following exposure for 48 hours to Ringer solution without (grey area) and with (black line) presence of $1 \mu \mathrm{g} / \mathrm{ml}$ ceritinib. B. Arithmetic means \pm SEM ( $\mathrm{n}=17)$ of the erythrocyte

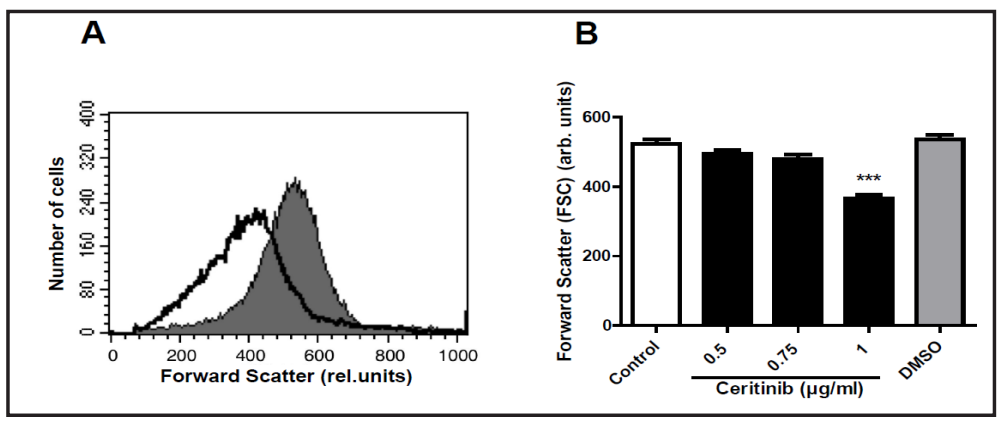
forward scatter (FSC) following incubation for 48 hours to Ringer solution without (white bar) or with (black bars) ceritinib $(0.5-1 \mu \mathrm{g} / \mathrm{ml})$. For comparison, the effect of the solvent DMSO is shown (grey bar). $* * *(p<0.001)$ indicates significant difference from the absence of ceritinib (ANOVA).

Fig. 3. Effect of ceritinib on hemolysis. Arithmetic means \pm SEM $(n=5)$ of the percentage of hemolytic erythrocytes following incubation for 48 hours to Ringer solution without (white bar) or with (black bars) ceritinib $(0.5-1 \mu \mathrm{g} / \mathrm{ml})$. For comparison, the effect of the solvent DMSO is shown (grey bar). ${ }^{* * *}(\mathrm{p}<0.001)$ indicates significant difference from the absence of ceritinib (ANOVA).

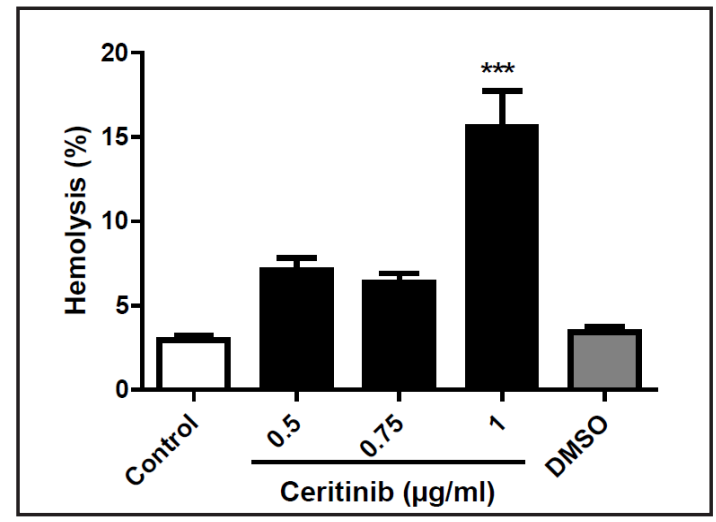

Hemoglobin concentration in the supernatant was taken as a measure of hemolysis. The erythrocytes were again incubated 48 hours prior to measurements in Ringer solution without or with ceritinib $(0.5-1 \mu \mathrm{g} / \mathrm{ml})$. As shown in Fig. 3, a 48 hours exposure to ceritinib increased the percentage of hemolytic erythrocytes, an effect statistically significant at $1 \mu \mathrm{g} /$ ml ceritinib.

Fluo3 fluorescence was taken as a measure of cytosolic $\mathrm{Ca}^{2+}$ activity $\left(\left[\mathrm{Ca}^{2+}\right]_{\mathrm{i}}\right)$. The erythrocytes were again incubated for 48 hours prior to measurements in Ringer solution either without or with ceritinib $(0.5-1 \mu \mathrm{g} / \mathrm{ml})$. As illustrated in Fig. 4, ceritinib increased Fluo3 fluorescence, an effect again reaching statistical significance at $1 \mu \mathrm{g} / \mathrm{ml}$ ceritinib concentration.

A further series of experiments explored whether the ceritinib-induced translocation of phosphatidylserine required entry of extracellular $\mathrm{Ca}^{2+}$. To this end, erythrocytes were 
Fig. 4. Effect of ceritinib on cytosolic $\mathrm{Ca}^{2+}$ activity. A. Original histogram of Fluo3-fluorescence reflecting cytosolic $\mathrm{Ca}^{2+}$ activity of erythrocytes following exposure for 48 hours to Ringer solution without (grey area) and with (black line) presence of $1 \mu \mathrm{g} /$ $\mathrm{ml}$ ceritinib. B. Arithmetic

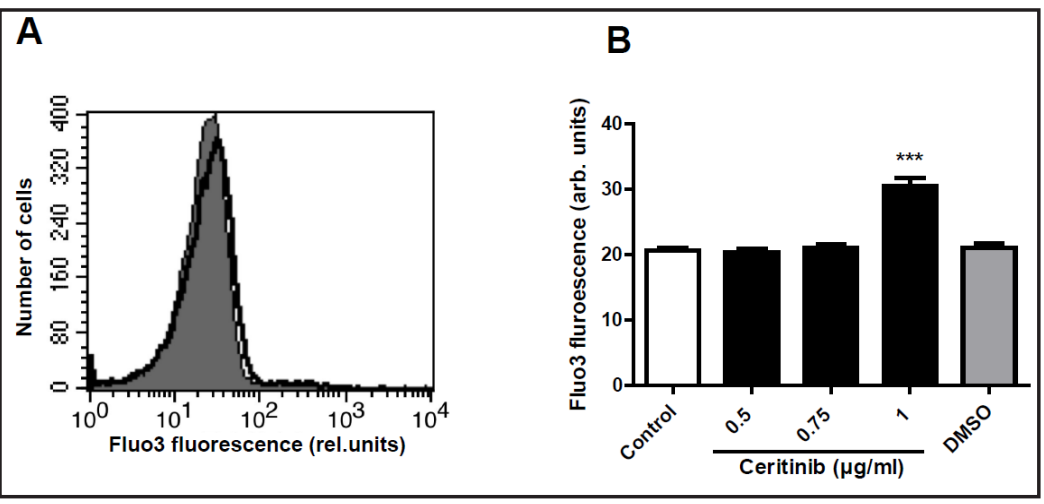
means \pm SEM $(n=17)$ of Fluo3-fluorescence in erythrocytes following incubation for 48 hours to Ringer solution without (white bar) or with (black bars) ceritinib $(0.5-1 \mu \mathrm{g} / \mathrm{ml})$. For comparison, the effect of the solvent DMSO is shown (grey bar). ${ }^{* *}(\mathrm{p}<0.001)$ indicates significant difference from the absence of ceritinib (ANOVA).

Fig. 5. $\mathrm{Ca}^{2+}$ sensitivity of ceritinib -induced phosphatidylserine exposure. A,B. Original histogram of annexin-V-binding of erythrocytes following exposure for 48 hours to Ringer solution without (grey areas) and with (black lines) ceritinib $(1 \mu \mathrm{g} / \mathrm{ml})$ in the presence (A) and absence (B) of extracellular $\mathrm{Ca}^{2+}$. C. Arithmetic means \pm SEM $(n=17)$ of annexinV-binding of erythrocytes after a 48 hours treatment with Ringer solution without (white bars) or with (black bars) ceritinib (1 $\mu \mathrm{g} / \mathrm{ml}$ ) in the presence (left bars, $+\mathrm{Ca}^{2+}$ ) and absence (right bars,

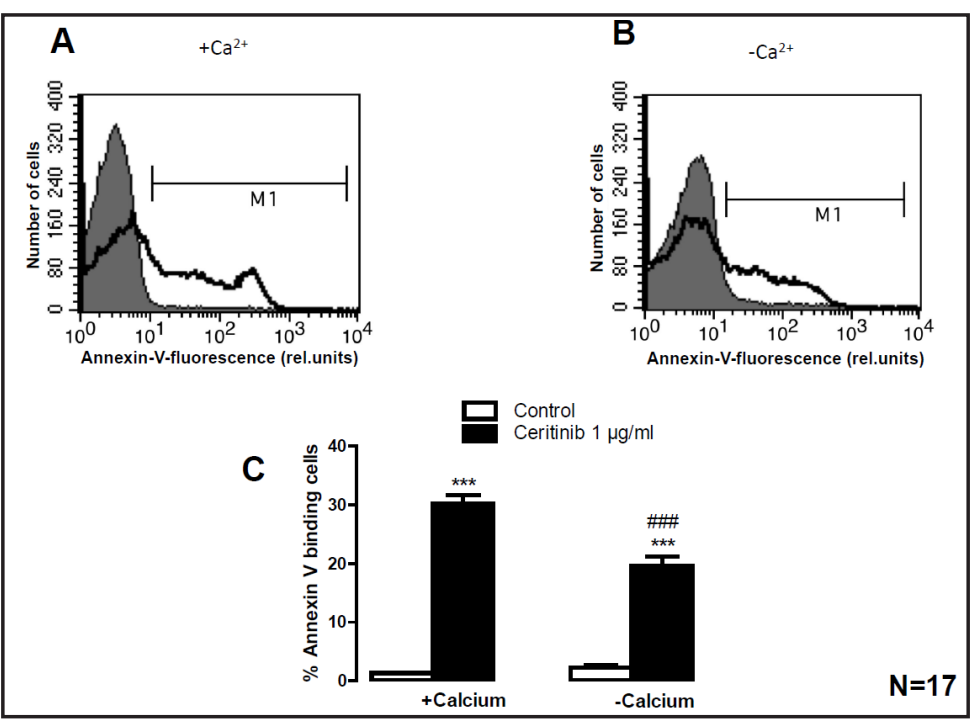
$\left.-\mathrm{Ca}^{2+}\right)$ of $\mathrm{Ca}^{2+} .{ }^{* * *}(\mathrm{p}<0.001)$ indicates significant difference from the absence of ceritinib (ANOVA). \#\#\# $(\mathrm{p}<0.001)$ indicates significant difference from the presence of calcium.

incubated for 48 hours in the absence or presence of $1 \mu \mathrm{g} / \mathrm{ml}$ ceritinib in the presence or nominal absence of extracellular $\mathrm{Ca}^{2+}$. As illustrated in Fig. 5, removal of extracellular $\mathrm{Ca}^{2+}$ significantly blunted the effect of ceritinib on annexin-V-binding. However, even in the absence of extracellular $\mathrm{Ca}^{2+}$, ceritinib significantly increased the percentage of annexin-Vbinding erythrocytes (Fig. 5). Thus, the ceritinib-induced cell membrane scrambling was in part triggered by mechanisms other than entry of extracellular $\mathrm{Ca}^{2+}$.

Eryptosis is further stimulated by oxidative stress. Reactive oxygen species (ROS) were thus quantified utilizing 2',7'-dichlorodihydrofluorescein diacetate (DCFDA) following a 48 hours incubation in Ringer solution without or with ceritinib $(1 \mu \mathrm{g} / \mathrm{ml})$. As a result, the DCFDA fluorescence was similar following exposure to $1 \mu \mathrm{g} / \mathrm{ml}$ ceritinib $(22.06 \pm 1.16$ a.u., $n=9$ ) and in the absence of ceritinib (20.71 \pm 0.61 a.u., $n=9)$. Thus, ceritinib did not appreciably induce oxidative stress.

A further stimulator of eryptosis is ceramide. Ceramide abundance at the erythrocyte surface was thus quantified utilizing specific antibodies after a 48 hours incubation of the erythroctyes in Ringer solution without or with ceritinib $(1 \mu \mathrm{g} / \mathrm{ml})$. The ceramide abundance was similar following exposure to $1 \mu \mathrm{g} / \mathrm{ml}$ ceritinib $(20.56 \pm 2.29$ a.u., $\mathrm{n}=10)$ and in the 
Fig. 6. Staurosporine sensitivity of ceritinib -induced phosphatidylserine exposure. A,B. Original histogram of annexin-V-binding of erythrocytes following exposure for 48 hours to Ringer solution without (grey areas) and with (black lines) ceritinib $(1 \mu \mathrm{g} / \mathrm{ml})$ in the absence (A) and presence (B) of staurosporine $(1 \mu \mathrm{M})$. C. Arithmetic means \pm SEM $(n=23)$ of annexinV-binding of erythrocytes after a 48 hours treatment with Ringer solution without (white bars) or with (black bars) ceritinib ( $1 \mu \mathrm{g} / \mathrm{ml})$ in the absence (left bars) and presence (right bars) of staurosporine $(1 \mu \mathrm{M})$. $* * *(\mathrm{p}<0.001)$ indicates significant difference from the absence of ceritinib, $\#(p<0.05)$ indicates significant

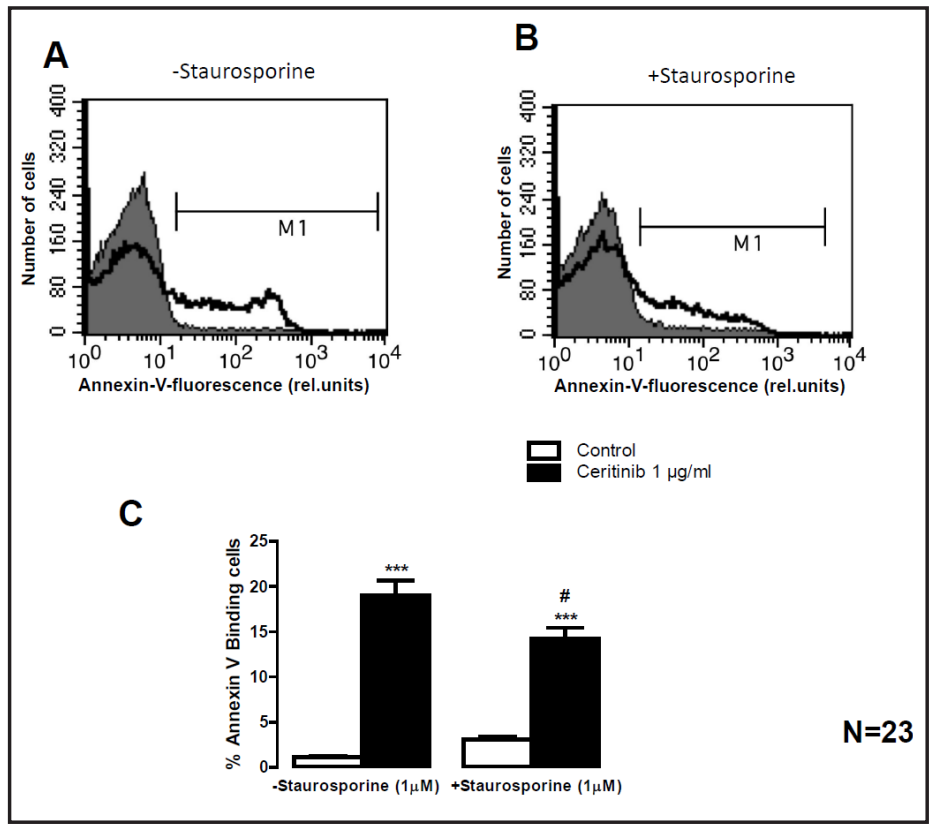
difference from the absence of staurosporine (ANOVA).

Fig. 7. SB203580 sensitivity of ceritinib-induced phosphatidylserine exposure. A,B. Original histogram of annexin-V-binding of erythrocytes following exposure for 48 hours to Ringer solution without (grey areas) and with (black lines) ceritinib (1 $\mu \mathrm{g} / \mathrm{ml}$ ) in the absence (A) and presence (B) of SB203580 (2 $\mu \mathrm{M})$. C. Arithmetic means \pm SEM $(n=23)$ of annexin-V-binding of erythrocytes after a 48 hours treatment with Ringer solution without (white bars) or with (black bars) ceritinib $(1 \mu \mathrm{g}$ / $\mathrm{ml}$ ) in the absence (left bars) and presence (right bars) of SB203580 $(2 \mu \mathrm{M}) .{ }^{* * *}(\mathrm{p}<0.001)$ indicates significant difference from the absence

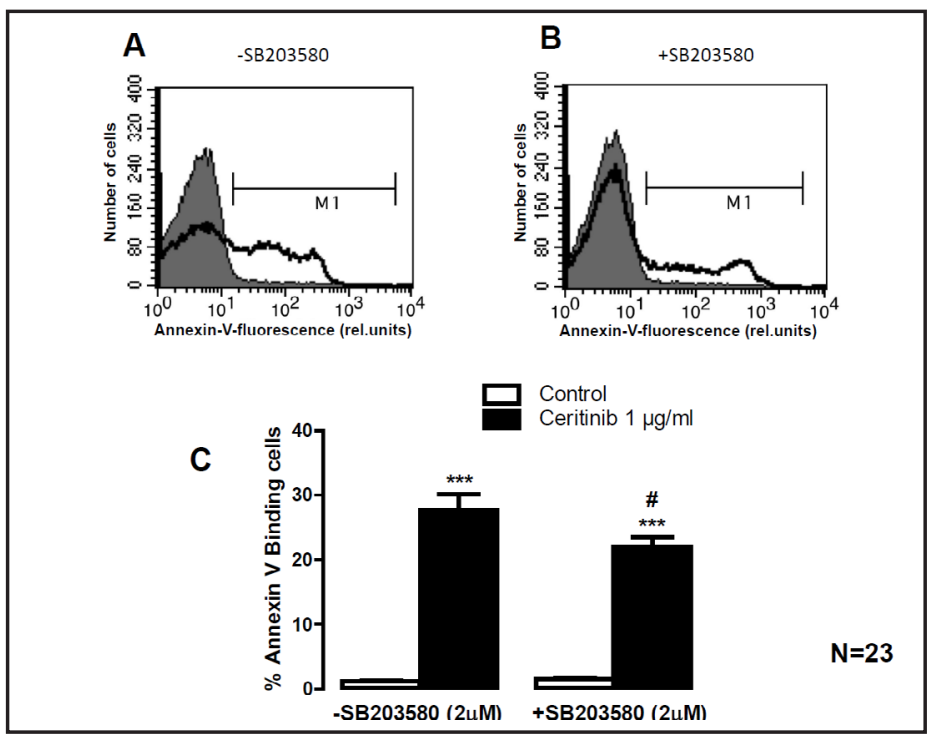
of ceritinib, $\#(p<0.05)$ indicates significant difference from the absence of SB203580 (2 $\mu \mathrm{M})$ (ANOVA).

absence of ceritinib (19.34 \pm 1.94 a.u., $\mathrm{n}=10)$. Accordingly, ceritinib did not appreciably increase ceramide abundance.

To explore, whether the effects of ceritinib involved kinase activity, the influence of ceritinib on annexin-V-binding was tested in the absence and presence of kinase inhibitors. As illustrated in Fig. 6, addition of staurosporine $(1 \mu \mathrm{M})$ significantly blunted the effect of ceritinib on annexin-V-binding. However, even in the presence of staurosporine, ceritinib significantly increased the percentage of annexin-V-binding erythrocytes (Fig. 6). Thus, the ceritinib-induced cell membrane scrambling was in part dependent on staurosporine sensitive kinases. As shown in Fig. 7, addition of p38 kinase inhibitor SB203580 (2 $\mu \mathrm{M})$ significantly blunted the effect of ceritinib on annexin-V-binding. Again, ceritinib significantly 
Fig. 8. D4476 sensitivity of ceritinib -induced phosphatidylserine exposure. A,B. Original histogram of annexin-V-binding of erythrocytes following exposure for 48 hours to Ringer solution without (grey areas) and with (black lines) ceritinib (1 $\mu \mathrm{g} / \mathrm{ml}$ ) in the absence (A) and presence (B) of D4476 (10 $\mu \mathrm{M})$. C. Arithmetic means \pm SEM ( $\mathrm{n}=15$ ) of annexin-V-binding of erythrocytes after a 48 hours treatment with Ringer solution without (white bars) or with (black bars) ceritinib $(1 \mu \mathrm{g} / \mathrm{ml})$ in the absence (left bars) and presence (right bars) of D4476 $(10 \mu \mathrm{M}){ }^{* * *}(\mathrm{p}<0.001)$ indicates

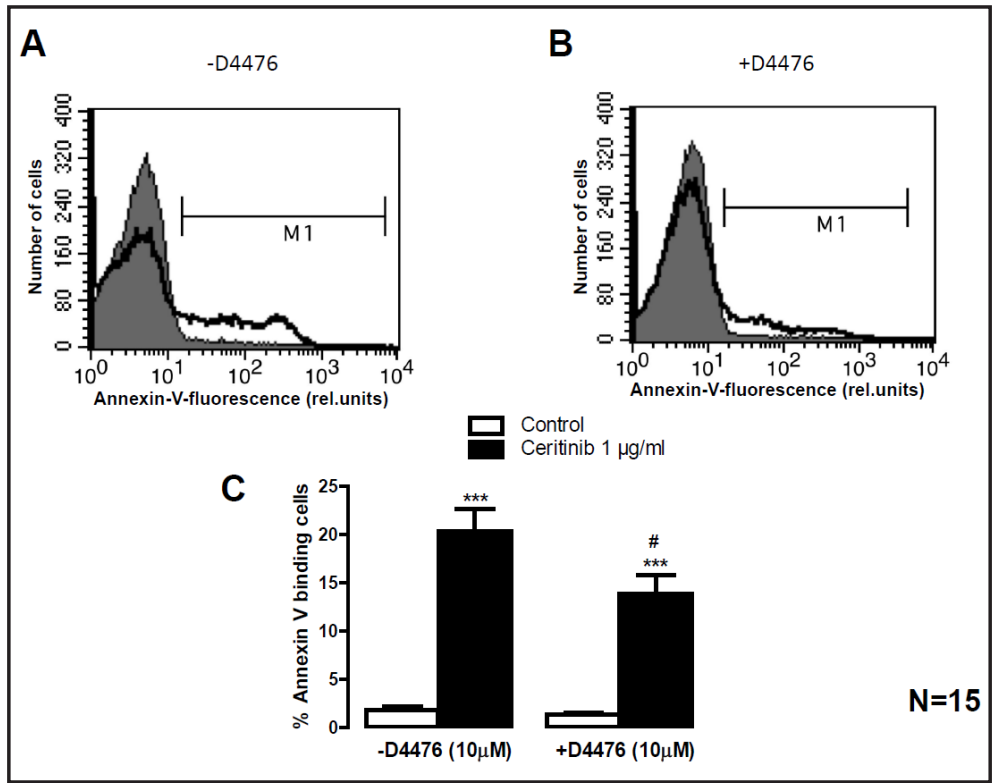
significant difference from the absence of ceritinib, $\#(p<0.05)$ indicates significant difference from the absence of D4476 $(10 \mu \mathrm{M})$ (ANOVA).

Fig. 9. zVAD sensitivity of ceritinib -induced phosphatidylserine exposure. A,B. Original histogram of annexin-V-binding of erythrocytes following exposure for 48 hours to Ringer solution without (grey areas) and with (black lines) ceritinib $(1 \mu \mathrm{g} / \mathrm{ml})$ in the absence (A) and presence (B) of zVAD $(10 \mu \mathrm{M})$. C. Arithmetic means \pm SEM $(n=11)$ of annexin-V-binding of erythrocytes after a 48 hours treatment with Ringer solution without (white bars) or with (black bars) ceritinib $(1 \mu \mathrm{g} / \mathrm{ml})$ in the absence (left bars) and presence (right bars) of zVAD $(10 \mu \mathrm{M})$.

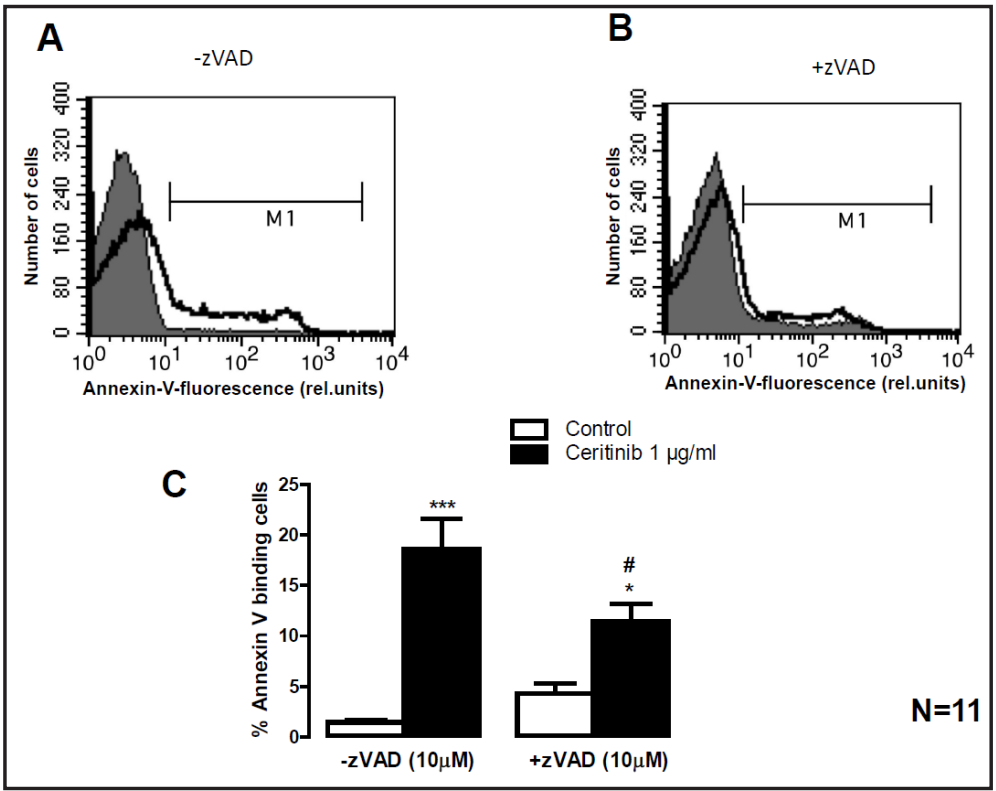
$*(p<0.05),{ }^{* * *}(p<0.001)$ indicates significant difference from the absence of ceritinib, $\#(p<0.05)$ indicates significant difference from the absence of zVAD $(10 \mu \mathrm{M})$ (ANOVA).

increased the percentage of annexin-V-binding erythrocytes even in the presence of SB203580 (Fig. 7). Thus, the ceritinib-induced cell membrane scrambling was partially but not fully dependent on p38 kinase. As illustrated in Fig. 8, addition of specific casein kinase 1 inhibitor D4476 $(10 \mu \mathrm{M})$ significantly blunted the effect of ceritinib on annexin-V-binding. However, ceritinib significantly increased the percentage of annexin-V-binding erythrocytes even in the presence of D4476 (Fig. 8). Thus, the ceritinib-induced cell membrane scrambling was in part but not completely dependent on casein kinase.

A final series of experiments explored the putative involvement of caspases. As shown in Fig. 9, addition of pan-caspase inhibitor zVAD $(10 \mu \mathrm{M})$ significantly blunted the effect of ceritinib on annexin-V-binding. However, even in the presence of zVAD, ceritinib significantly 
increased the percentage of annexin-V-binding erythrocytes (Fig. 9). Thus, the ceritinibinduced cell membrane scrambling was in part dependent on caspase activity.

\section{Discussion}

The present observations disclose a novel effect of ceritinib, i.e. the stimulation of suicidal erythrocyte death or eryptosis. Exposure of human erythrocytes to ceritinib results in cell shrinkage and cell membrane scrambling with phosphatidylserine translocation to the erythrocyte surface. The concentration required for the stimulation of eryptosis is well in the range of concentrations (up to $1.4 \mu \mathrm{g} / \mathrm{ml}$ ) encountered in plasma of patients [1]. Stimulation of eryptosis could thus well contribute to or even account for the ceritinib-induced anemia [2]. It must be kept in mind that the sensitivity to triggers of eryptosis is enhanced in several clinical conditions including iron deficiency [16], dehydration [72], hyperphosphatemia [73], chronic kidney disease (CKD) [74-77], hemolytic-uremic syndrome [78], diabetes [79], hepatic failure [63], malignancy [16], sepsis [80], sickle-cell disease [16], beta-thalassemia [16], Hb-C and G6PD-deficiency [16], as well as Wilsons disease [81].

The effect of ceritinib on cell membrane scrambling was paralleled by increase of cytosolic $\mathrm{Ca}^{2+}$ activity $\left(\left[\mathrm{Ca}^{2+}\right]_{\mathrm{i}}\right)$ and required in part $\mathrm{Ca}^{2+}$ entry from the extracellular space. Removal of extracellular $\mathrm{Ca}^{2+}$ significantly blunted the ceritinib-induced phosphatidylserine translocation. However, even in the nominal absence of extracellular $\mathrm{Ca}^{2+}$ ceritinib significantly stimulated cell membrane scrambling, an observation pointing to the involvement of additional mechanisms. Cells could be sensitized for the scrambling effect of $\mathrm{Ca}^{2+}$ by ceramide [16]. However, ceritinib triggered cell membrane scrambling without enhancing ceramide abundance. Moreover, ceritinib triggered eryptosis without inducing oxidative stress. Instead, the effect of ceritinib was sensitive to protein kinase C inhibitor staurosporine, p38 kinase inhibitor SB203580 and casein kinase inhibitor D4476. All those kinases have previously been shown to trigger eryptosis [16]. Moreover, the ceritinib-induced eryptosis was sensitive to caspases, which may, dependent on the trigger, participate in the stimulation of eryptosis [16]. Known stimulators of caspases in erythrocytes include oxidative stress $[16,19,20]$, which, however, appears to be absent following ceritinib treatment. Erythrocytes lack mitochondria and are thus unable to activate caspases through the mitochondrial pathway. The mechanism underlying ceritinibinduced caspase activation thus remained elusive.

The effect of ceritinib on cell shrinkage may similarly involve $\mathrm{Ca}^{2+}$ entry from the extracellular space, which is expected to increase $\left[\mathrm{Ca}^{2+}\right]_{\mathrm{i}}$ with subsequent activation of $\mathrm{Ca}^{2+}$ sensitive $\mathrm{K}^{+}$channels, $\mathrm{K}^{+}$exit, cell membrane hyperpolarization, $\mathrm{Cl}^{-}$exit and thus cellular loss of $\mathrm{KCl}$ with water.

Ceritinib tended to increase hemolysis at 0.5 and $0.75 \mu \mathrm{g} / \mathrm{ml}$, an effect, however, not reaching statistical significance. At $1 \mu \mathrm{g} / \mathrm{ml}$, ceritinib triggered a robust, statistically significant hemolysis. Unlike eryptosis [16], hemolysis leads to release of hemoglobin, which passes the renal glomerular filter, precipitates in the acidic lumen of renal tubules, occludes nephrons and thus causes renal failure [82].

As phosphatidylserine exposing erythrocytes are rapidly cleared from circulating blood, stimulation of eryptosis is followed by anemia as soon as the loss of erythrocytes outcasts the formation of new erythrocytes by erythropoiesis [16]. Anemia could further result from stimulated hemolysis and/or enhanced apoptosis of progenitor cells [83, 84]. Phosphatidylserine exposing erythrocytes may further compromize microcirculation [18, 85-89] due to adherence to the vascular wall [90], as well as stimulation of blood clotting and thrombosis $[85,91,92]$.

In conclusion, ceritinib triggers eryptosis with cell shrinkage and cell membrane scrambling, an effect in part due to $\mathrm{Ca}^{2+}$ entry, activation of staurosporine, SB203580 and D4476 sensitive kinases as well as caspases. The present observations may point to therapeutic options in the prevention of ceritinib-induced anemia. For instance, eryptosis were expected to be inhibited by skepinone, an anti-eryptotic p38 kinase inhibitor, which is effective in vivo [93]. 


\section{Cellular Physiology Cell Physiol Biochem 2016;40:1129-1140 \begin{tabular}{ll|l} 
and Biochemistry & Dublished online: December 14, 2016 & $\begin{array}{l}\text { (c) } 2016 \text { The Author(s). Published by S. Karger AG, Basel } \\
\text { www.karger.com/cpb }\end{array}$
\end{tabular} Bhuyan et al.: Ceritinib-Induced Eryptosis}

\section{Acknowledgements}

The authors acknowledge the meticulous preparation of the manuscript by Tanja Loch. The study was supported by the Deutsche Forschungsgemeinschaft and Open Access Publishing Fund of Tuebingen University.

\section{Disclosure Satement}

All authors declare that there are no conflicts of interest that could be perceived as prejudicing the impartiality of the research reported.

\section{References}

1 Nishio M, Murakami H, Horiike A, Takahashi T, Hirai F, Suenaga N, Tajima T, Tokushige K, Ishii M, Boral A, Robson M, Seto T: Phase I Study of Ceritinib (LDK378) in Japanese Patients with Advanced, Anaplastic Lymphoma Kinase-Rearranged Non-Small-Cell Lung Cancer or Other Tumors. J Thorac Oncol 2015;10:1058-1066.

2 Khozin S, Blumenthal GM, Zhang L, Tang S, Brower M, Fox E, Helms W, Leong R, Song P, Pan Y, Liu Q, Zhao P, Zhao H, Lu D, Tang Z, Al Hakim A, Boyd K, Keegan P, Justice R, Pazdur R: FDA approval: ceritinib for the treatment of metastatic anaplastic lymphoma kinase-positive non-small cell lung cancer. Clin Cancer Res 2015;21:2436-2439.

3 Cooper MR, Chim H, Chan H, Durand C: Ceritinib: a new tyrosine kinase inhibitor for non-small-cell lung cancer. Ann Pharmacother 2015;49:107-112.

$4 \quad$ Dhillon S, Clark M: Ceritinib: first global approval. Drugs 2014;74:1285-1291.

5 El-Osta H, Shackelford R: Personalized treatment options for ALK-positive metastatic non-small-cell lung cancer: potential role for Ceritinib. Pharmgenomics Pers Med 2015;8:145-154.

6 Giroux Leprieur E, Fallet V, Wislez M: [Modalities of use of ceritinib (Zykadia), a 2nd generation ALK inhibitor, in advanced stage non-small cell lung cancer]. Bull Cancer 2015;102:1053-1057.

7 Kaczmar J, Mehra R: The efficacy of ceritinib in patients with ALK-positive non-small cell lung cancer. Ther Adv Respir Dis 2015;9:236-241.

8 Kanaan Z, Kloecker GH, Paintal A, Perez CA: Novel targeted therapies for resistant ALK-rearranged nonsmall-cell lung cancer: ceritinib and beyond. Onco Targets Ther 2015;8:885-892.

9 Katayama R, Sakashita T, Yanagitani N, Ninomiya H, Horiike A, Friboulet L, Gainor JF, Motoi N, Dobashi A, Sakata S, Tambo Y, Kitazono S, Sato S, Koike S, John Iafrate A, Mino-Kenudson M, Ishikawa Y, Shaw AT, Engelman JA, Takeuchi K, Nishio M, Fujita N: P-glycoprotein Mediates Ceritinib Resistance in Anaplastic Lymphoma Kinase-rearranged Non-small Cell Lung Cancer. EBioMedicine 2016;3:54-66.

10 Landi L, Cappuzzo F: Ceritinib for the treatment of non-small cell lung cancer. Drugs Today (Barc) 2014;50:465-473.

11 Li S, Qi X, Huang Y, Liu D, Zhou F, Zhou C: Ceritinib (LDK378): a potent alternative to crizotinib for ALKrearranged non-small-cell lung cancer. Clin Lung Cancer 2015;16:86-91.

12 Massarelli E, Papadimitrakopoulou V: Ceritinib for the treatment of late-stage (metastatic) non-small cell lung cancer. Clin Cancer Res 2015;21:670-674.

13 Nix NM, Brown KS: Ceritinib for ALK-Rearrangement-Positive Non-Small Cell Lung Cancer. J Adv Pract Oncol 2015;6:156-160.

14 Rothschild SI: New treatment options for ALK+ advanced non-small-cell lung cancer: critical appraisal of ceritinib. Ther Clin Risk Manag 2016;12:735-741.

15 Vansteenkiste JF: Ceritinib for treatment of ALK-rearranged advanced non-small-cell lung cancer. Future Oncol 2014;10:1925-1939.

16 Lang E, Lang F: Mechanisms and pathophysiological significance of eryptosis, the suicidal erythrocyte death. Semin Cell Dev Biol 2015;39:35-42.

17 Lang PA, Kaiser S, Myssina S, Wieder T, Lang F, Huber SM: Role of Ca2+-activated K+ channels in human erythrocyte apoptosis. Am J Physiol Cell Physiol 2003;285:C1553-C1560.

18 Abed M, Towhid ST, Mia S, Pakladok T, Alesutan I, Borst O, Gawaz M, Gulbins E, Lang F: Sphingomyelinaseinduced adhesion of eryptotic erythrocytes to endothelial cells. Am J Physiol Cell Physiol 2012;303:C991999. 


\section{Cellular Physiology Cell Physiol Biochem 2016;40:1129-1140 \begin{tabular}{l|l|l} 
DOI: 10.1159/000453167 & $\begin{array}{l}\text { C } 2016 \text { The Author(s). Published by S. Karger AG, Basel } \\
\text { www.karger.com/cpb }\end{array}$
\end{tabular} \\ Bhuyan et al.: Ceritinib-Induced Eryptosis}

19 Lau IP, Chen H, Wang J, Ong HC, Leung KC, Ho HP, Kong SK: In vitro effect of CTAB- and PEG-coated gold nanorods on the induction of eryptosis/erythroptosis in human erythrocytes. Nanotoxicology 2012;6:847856.

20 Maellaro E, Leoncini S, Moretti D, Del Bello B, Tanganelli I, De Felice C, Ciccoli L: Erythrocyte caspase-3 activation and oxidative imbalance in erythrocytes and in plasma of type 2 diabetic patients. Acta Diabetol 2013;50:489-495.

21 Zelenak C, Eberhard M, Jilani K, Qadri SM, Macek B, Lang F: Protein kinase CK1alpha regulates erythrocyte survival. Cell Physiol Biochem 2012;29:171-180.

22 Bhavsar SK, Gu S, Bobbala D, Lang F: Janus kinase 3 is expressed in erythrocytes, phosphorylated upon energy depletion and involved in the regulation of suicidal erythrocyte death. Cell Physiol Biochem 2011;27:547-556.

23 Schneider J, Nicolay JP, Foller M, Wieder T, Lang F: Suicidal erythrocyte death following cellular K+ loss. Cell Physiol Biochem 2007;20:35-44.

24 Gatidis S, Zelenak C, Fajol A, Lang E, Jilani K, Michael D, Qadri SM, Lang F: p38 MAPK activation and function following osmotic shock of erythrocytes. Cell Physiol Biochem 2011;28:1279-1286.

25 Foller M, Sopjani M, Koka S, Gu S, Mahmud H, Wang K, Floride E, Schleicher E, Schulz E, Munzel T, Lang F: Regulation of erythrocyte survival by AMP-activated protein kinase. FASEB J 2009;23:1072-1080.

26 Foller M, Feil S, Ghoreschi K, Koka S, Gerling A, Thunemann M, Hofmann F, Schuler B, Vogel J, Pichler B, Kasinathan RS, Nicolay JP, Huber SM, Lang F, Feil R: Anemia and splenomegaly in cGKI-deficient mice. Proc Natl Acad Sci U S A 2008;105:6771-6776.

27 Zelenak C, Foller M, Velic A, Krug K, Qadri SM, Viollet B, Lang F, Macek B: Proteome analysis of erythrocytes lacking AMP-activated protein kinase reveals a role of PAK2 kinase in eryptosis. J Proteome Res 2011;10:1690-1697.

28 Shaik N, Lupescu A, Lang F: Sunitinib-sensitive suicidal erythrocyte death. Cell Physiol Biochem 2012;30:512-522.

29 Lupescu A, Shaik N, Jilani K, Zelenak C, Lang E, Pasham V, Zbidah M, Plate A, Bitzer M, Foller M, Qadri SM, Lang F: Enhanced erythrocyte membrane exposure of phosphatidylserine following sorafenib treatment: an in vivo and in vitro study. Cell Physiol Biochem 2012;30:876-888.

30 Alzoubi K, Calabrò S, Bissinger R, Abed M, Faggio C, Lang F: Stimulation of Suicidal Erythrocyte Death by Artesunate. Cell Physiol Biochem 2014;34:2232-2244.

31 Alzoubi K, Egler J, Abed M, Lang F: Enhanced Eryptosis Following Auranofin Exposure. Cell Physiol Biochem 2015;37:1018-1028.

32 Arnold M, Bissinger R, Lang F: Mitoxantrone-induced suicidal erythrocyte death. Cell Physiol Biochem 2014;34:1756-1767.

33 Arnold M, Lang E, Modicano P, Bissinger R, Faggio C, Abed M, Lang F: Effect of nitazoxanide on erythrocytes. Basic Clin Pharmacol Toxicol 2014;114:421-426.

34 Bissinger R, Barking S, Alzoubi K, Liu G, Liu G, Lang F: Stimulation of Suicidal Erythrocyte Death by the Antimalarial Drug Mefloquine. Cell Physiol Biochem 2015;36:1395-1405.

35 Bissinger R, Bouguerra G, Stockinger K, Abbes S, Lang F: Triggering of Suicidal Erythrocyte Death by Topotecan. Cell Physiol Biochem 2015;37:1607-1618.

36 Bissinger R, Fischer S, Jilani K, Lang F: Stimulation of Erythrocyte Death by Phloretin. Cell Physiol Biochem 2014;34:2256-2265.

37 Bissinger R, Lupescu A, Zelenak C, Jilani K, Lang F: Stimulation of eryptosis by cryptotanshinone. Cell Physiol Biochem 2014;34:432-442.

38 Bouguerra G, Aljanadi O, Bissinger R, Abbes S, Lang F: Embelin-Induced Phosphatidylserine Translocation in the Erythrocyte Cell Membrane. Cell Physiol Biochem 2015;37:1629-1640.

39 Bouguerra G, Bissinger R, Abbes S, Lang F: Stimulation of Eryptosis by Narasin. Cell Physiol Biochem 2015;37:1807-1816.

40 Bouguerra G, Bissinger R, Abbes S, Lang F: Zopolrestat Induced Suicidal Death of Human Erythrocytes. Cell Physiol Biochem 2015;37:1537-1546.

41 Briglia M, Fazio A, Faggio C, Laufer S, Alzoubi K, Lang F: Triggering of Suicidal Erythrocyte Death by Ruxolitinib. Cell Physiol Biochem 2015;37:768-778.

42 Briglia M, Fazio A, Signoretto E, Faggio C, Lang F: Edelfosine Induced Suicidal Death of Human Erythrocytes. Cell Physiol Biochem 2015;37:2221-2230.

43 Calabro S, Alzoubi K, Faggio C, Laufer S, Lang F: Triggering of Suicidal Erythrocyte Death Following Boswellic Acid Exposure. Cell Physiol Biochem 2015;37:131-142.

44 Egler J, Lang F: Licochalcone A Induced Suicidal Death of Human Erythrocytes. Cell Physiol Biochem 2015;37:2060-2070. 


\section{Cellular Physiology Cell Physiol Biochem 2016;40:1129-1140 \begin{tabular}{l|l|l|} 
and BOI: 10.1159/000453167 & $\begin{array}{l}\text { C) 2016 The Author(s). Published by S. Karger AG, Basel } \\
\text { www.karger.com/cpb }\end{array}$ \\
\hline Published online: December 14, 2016
\end{tabular} \\ Bhuyan et al.: Ceritinib-Induced Eryptosis}

45 Faggio C, Alzoubi K, Calabro S, Lang F: Stimulation of suicidal erythrocyte death by PRIMA-1. Cell Physiol Biochem 2015;35:529-540.

46 Fazio A, Briglia M, Faggio C, Alzoubi K, Lang F: Stimulation of Suicidal Erythrocyte Death by Garcinol. Cell Physiol Biochem 2015;37:805-815.

47 Jacobi J, Lang E, Bissinger R, Frauenfeld L, Modicano P, Faggio C, Abed M, Lang F: Stimulation of erythrocyte cell membrane scrambling by mitotane. Cell Physiol Biochem 2014;33:1516-1526.

48 Lang E, Jilani K, Bissinger R, Rexhepaj R, Zelenak C, Lupescu A, Lang F, Qadri SM: Vitamin D-Rich Diet in Mice Modulates Erythrocyte Survival. Kidney Blood Press Res 2015;40:403-412.

49 Lupescu A, Bissinger R, Goebel T, Salker MS, Alzoubi K, Liu G, Chirigiu L, Mack AF, Qadri SM, Lang F: Enhanced suicidal erythrocyte death contributing to anemia in the elderly. Cell Physiol Biochem 2015;36:773-783.

50 Lupescu A, Bissinger R, Herrmann T, Oswald G, Jilani K, Lang F: Induction of suicidal erythrocyte death by novobiocin. Cell Physiol Biochem 2014;33:670-680.

51 Malik A, Bissinger R, Calabro S, Faggio C, Jilani K, Lang F: Aristolochic Acid Induced Suicidal Erythrocyte Death. Kidney Blood Press Res 2014;39:408-419.

52 Officioso A, Alzoubi K, Manna C, Lang F: Clofazimine Induced Suicidal Death of Human Erythrocytes. Cell Physiol Biochem 2015;37:331-341.

53 Oswald G, Alzoubi K, Abed M, Lang F: Stimulation of suicidal erythrocyte death by ribavirin. Basic Clin Pharmacol Toxicol 2014;114:311-317.

54 Peter T, Bissinger R, Enkel S, Alzoubi K, Oswald G, Lang F: Programmed erythrocyte death following in vitro Treosulfan treatment. Cell Physiol Biochem 2015;35:1372-1380.

55 Stockinger K, Bissinger R, Bouguerra G, Abbes S, Lang F: Enhanced Eryptosis Following Exposure to Carnosic Acid. Cell Physiol Biochem 2015;37:1779-1791.

56 Tesoriere L, Attanzio A, Allegra M, Cilla A, Gentile C, Livrea MA: Oxysterol mixture in hypercholesterolemiarelevant proportion causes oxidative stress-dependent eryptosis. Cell Physiol Biochem 2014;34:10751089.

57 Waibel S, Bissinger R, Bouguerra G, Abbes S, Lang F: Saquinavir Induced Suicidal Death of Human Erythrocytes. Cell Physiol Biochem 2015;37:1973-1982.

58 Zierle J, Bissinger R, Egler J, Lang F: Lapatinib Induced Suicidal Death of Human Erythrocytes. Cell Physiol Biochem 2015;37:2275-2287.

59 Bissinger R, Bouguerra G, Al Mamun Bhuyan A, Waibel S, Abbes S, Lang F: Efavirenz Induced Suicidal Death of Human Erythrocytes. Cell Physiol Biochem 2015;37:2496-2507.

60 Bissinger R, Waibel S, Bouguerra G, Al Mamun Bhuyan A, Abbes S, Lang F: Enhanced Eryptosis Following Exposure to Lopinavir. Cell Physiol Biochem 2015;37:2486-2495.

61 Briglia M, Calabro S, Signoretto E, Alzoubi K, Laufer S, Faggio C, Lang F: Fucoxanthin Induced Suicidal Death of Human Erythrocytes. Cell Physiol Biochem 2015;37:2464-2475.

62 Briglia M, Fazio A, Faggio C, Lang F: Triggering of Suicidal Erythrocyte Death by Zosuquidar. Cell Physiol Biochem 2015;37:2355-2365.

63 Fazio A, Briglia M, Faggio C, Alzoubi K, Lang F: Oxaliplatin Induced Suicidal Death of Human Erythrocytes. Cell Physiol Biochem 2015;37:2393-2404.

64 Macczak A, Cyrkler M, Bukowska B, Michalowicz J: Eryptosis-inducing activity of bisphenol A and its analogs in human red blood cells (in vitro study). J Hazard Mater 2016;307:328-335.

65 Officioso A, Alzoubi K, Lang F, Manna C: Hydroxytyrosol inhibits phosphatidylserine exposure and suicidal death induced by mercury in human erythrocytes: Possible involvement of the glutathione pathway. Food Chem Toxicol 2016;89:47-53.

66 Officioso A, Manna C, Alzoubi K, Lang F: Bromfenvinphos induced suicidal death of human erythrocytes. Pestic Biochem Physiol 2016;126:58-63.

67 Qadri SM, Donkor DA, Bhakta V, Eltringham-Smith LJ, Dwivedi DJ, Moore JC, Pepler L, Ivetic N, Nazi I, Fox-Robichaud AE, Liaw PC, Sheffield WP: Phosphatidylserine externalization and procoagulant activation of erythrocytes induced by Pseudomonas aeruginosa virulence factor pyocyanin. J Cell Mol Med 2016;10.1111/jcmm.12778

68 Zierle J, Bissinger R, Bouguerra G, Abbes S, Lang F: Triggering of Suicidal Erythrocyte Death by Regorafenib. Cell Physiol Biochem 2016;38:160-172.

69 Pagano M, Faggio C: The use of erythrocyte fragility to assess xenobiotic cytotoxicity. Cell Biochem Funct 2015;33:351-355.

70 Bissinger R, Modicano P, Alzoubi K, Honisch S, Faggio C, Abed M, Lang F: Effect of saponin on erythrocytes. Int J Hematol 2014;100:51-59. 


\section{Cellular Physiology Cell Physiol Biochem 2016;40:1129-1140 \begin{tabular}{l|l|l} 
DOI: 10.1159/000453167 & $\begin{array}{l}\text { C } 2016 \text { The Author(s). Published by S. Karger AG, Basel } \\
\text { www.karger.com/cpb }\end{array}$
\end{tabular} \\ Bhuyan et al.: Ceritinib-Induced Eryptosis}

71 Bissinger R, Modicano P, Frauenfeld L, Lang E, Jacobi J, Faggio C, Lang F: Estramustine-induced suicidal erythrocyte death. Cell Physiol Biochem 2013;32:1426-1436.

72 Abed M, Feger M, Alzoubi K, Pakladok T, Frauenfeld L, Geiger C, Towhid ST, Lang F: Sensitization of erythrocytes to suicidal erythrocyte death following water deprivation. Kidney Blood Press Res 2013;37:567-578.

73 Voelkl J, Alzoubi K, Mamar AK, Ahmed MS, Abed M, Lang F: Stimulation of suicidal erythrocyte death by increased extracellular phosphate concentrations. Kidney Blood Press Res 2013;38:42-51.

74 Abed M, Artunc F, Alzoubi K, Honisch S, Baumann D, Foller M, Lang F: Suicidal erythrocyte death in endstage renal disease. J Mol Med (Berl) 2014;92:871-879.

75 Ahmed MS, Langer H, Abed M, Voelkl J, Lang F: The uremic toxin acrolein promotes suicidal erythrocyte death. Kidney Blood Press Res 2013;37:158-167.

76 Polak-Jonkisz D, Purzyc L: Ca(2+) influx versus efflux during eryptosis in uremic erythrocytes. Blood Purif 2012;34:209-210; author reply 210.

77 Calderon-Salinas JV, Munoz-Reyes EG, Guerrero-Romero JF, Rodriguez-Moran M, Bracho-Riquelme RL, Carrera-Gracia MA, Quintanar-Escorza MA: Eryptosis and oxidative damage in type 2 diabetic mellitus patients with chronic kidney disease. Mol Cell Biochem 2011;357:171-179.

78 Lang PA, Beringer O, Nicolay JP, Amon O, Kempe DS, Hermle T, Attanasio P, Akel A, Schafer R, Friedrich B, Risler T, Baur M, Olbricht CJ, Zimmerhackl LB, Zipfel PF, Wieder T, Lang F: Suicidal death of erythrocytes in recurrent hemolytic uremic syndrome. J Mol Med (Berl) 2006;84:378-388.

79 Nicolay JP, Schneider J, Niemoeller OM, Artunc F, Portero-Otin M, Haik G Jr., Thornalley PJ, Schleicher E, Wieder T, Lang F: Stimulation of suicidal erythrocyte death by methylglyoxal. Cell Physiol Biochem 2006;18:223-232.

80 Kempe DS, Akel A, Lang PA, Hermle T, Biswas R, Muresanu J, Friedrich B, Dreischer P, Wolz C, Schumacher U, Peschel A, Gotz F, Doring G, Wieder T, Gulbins E, Lang F: Suicidal erythrocyte death in sepsis. J Mol Med (Berl) 2007;85:273-281.

81 Lang PA, Schenck M, Nicolay JP, Becker JU, Kempe DS, Lupescu A, Koka S, Eisele K, Klarl BA, Rubben H, Schmid KW, Mann K, Hildenbrand S, Hefter H, Huber SM, Wieder T, Erhardt A, Haussinger D, Gulbins E, Lang F: Liver cell death and anemia in Wilson disease involve acid sphingomyelinase and ceramide. Nat Med 2007;13:164-170.

82 Harrison HE, Bunting H, Ordway NK, Albrink WS: The Pathogenesis of the Renal Injury Produced in the Dog by Hemoglobin or Methemoglobin. J Exp Med 1947;86:339-356.

83 Koury MJ, Rhodes M: How to approach chronic anemia. Hematology Am Soc Hematol Educ Program 2012;2012:183-190.

84 Shih AW, McFarlane A, Verhovsek M: Haptoglobin testing in hemolysis: measurement and interpretation. Am J Hematol 2014;89:443-447.

85 Andrews DA, Low PS: Role of red blood cells in thrombosis. Curr Opin Hematol 1999;6:76-82.

86 Closse C, Dachary-Prigent J, Boisseau MR: Phosphatidylserine-related adhesion of human erythrocytes to vascular endothelium. Br J Haematol 1999;107:300-302.

87 Gallagher PG, Chang SH, Rettig MP, Neely JE, Hillery CA, Smith BD, Low PS: Altered erythrocyte endothelial adherence and membrane phospholipid asymmetry in hereditary hydrocytosis. Blood 2003;101:46254627.

88 Pandolfi A, Di Pietro N, Sirolli V, Giardinelli A, Di Silvestre S, Amoroso L, Di Tomo P, Capani F, Consoli A, Bonomini M: Mechanisms of uremic erythrocyte-induced adhesion of human monocytes to cultured endothelial cells. J Cell Physiol 2007;213:699-709.

89 Wood BL, Gibson DF, Tait JF: Increased erythrocyte phosphatidylserine exposure in sickle cell disease: flowcytometric measurement and clinical associations. Blood 1996;88:1873-1880.

90 Borst O, Abed M, Alesutan I, Towhid ST, Qadri SM, Foller M, Gawaz M, Lang F: Dynamic adhesion of eryptotic erythrocytes to endothelial cells via CXCL16/SR-PSOX. Am J Physiol Cell Physiol 2012;302:C644-C651.

91 Chung SM, Bae ON, Lim KM, Noh JY, Lee MY, Jung YS, Chung JH: Lysophosphatidic acid induces thrombogenic activity through phosphatidylserine exposure and procoagulant microvesicle generation in human erythrocytes. Arterioscler Thromb Vasc Biol 2007;27:414-421.

92 Zwaal RF, Comfurius P, Bevers EM: Surface exposure of phosphatidylserine in pathological cells. Cell Mol Life Sci 2005;62:971-988.

93 Koeberle SC, Romir J, Fischer S, Koeberle A, Schattel V, Albrecht W, Grutter C, Werz O, Rauh D, Stehle T, Laufer SA: Skepinone-L is a selective p38 mitogen-activated protein kinase inhibitor. Nat Chem Biol 2011;8:141-143. 